\title{
FREKUENSI ALEL GOLONGAN DARAH SISTEM A-B-O PADA POPULASI SUKU OSING DESA KEMIREN KABUPATEN BANYUWANGI
}

\section{ALLELE FREQUENCY OF A-B-O BLOOD GROUP IN "OSING" POPULATION OF KEMIREN VILLAGE-BANYUWANGI}

\author{
Novita Amania ${ }^{1)}$, Hidayat Teguh Wiyono ${ }^{2)}$, Rike Oktarianti ${ }^{3)}$ \\ ${ }^{1), 2), 3)}$ Program Studi Biologi, FMIPA, Universitas Jember, Indonesia. \\ Email: rike.fmipa@unej.ac.id
}

diterima : 26 Desember 2019; dipublikasi : 30 Maret 2020

DOI: $10.32528 /$ bioma.v5i1.3680

\begin{abstract}
ABSTRAK
Suku Osing di desa Kemiren, Banyuwangi memiliki tradisi perkawinan upekupekkan, yaitu perkawinan antar kerabat. Perkawinan ini termasuk dalam perkawinan endogami yang menyebabkan menurunnya variasi genetik. Penelitian ini bertujuan untuk mengetahui proporsi fenotip, frekuensi alel, dan kesetimbangan genetic HardyWeinberg golongan darah ABO pada populasi suku Osing di Desa Kemiren. Pengambilan sampel dilakukan secara acak. Identifikasi golongan darah dilakukan dengan metode slide test. Analisis penelitian menggunakan uji Chi-square. Hasil penelitian menunjukkan golongan darah pada populasi suku Osing di Desa Kemiren sebagai berikut: golongan darah $\mathrm{O}(45,95 \%)$, A $(23,99 \%)$, B $(21,97 \%)$, dan $\mathrm{AB}$ $(8,09 \%)$. Frekuensi alel masing-masing adalah alel $\mathrm{I}^{\mathrm{A}}(0,16)$, frekuensi alel $\mathrm{I}^{\mathrm{B}}(0,16)$, dan frekuensi alel i $(0,68)$. Hasil pengujian kesetimbangan genetik Hardy-Weinberg dengan uji Chi-square menunjukkan tidak ada penyimpangan yang signifikan.
\end{abstract}

Kata kunci : ABO, Frekuensi alel, Suku Osing, Hardy-Weinberg

\section{ABSTRACT}

The Osing population is a resident in Kemiren village-Banyuwangi who is married as a called upek-upekan. Upek-upekkan is referred as endogamy marriage. This study aims to determine the phenotypic proportions, allele frequencies, and determined Hardy-Weinberg's genetic equilibrium at the $\mathrm{ABO}$ blood group allele frequency in the Osing population. Sampling is randomly design and identification of blood type by the" slide test" method. The data analysis using Chi-square test. The results showed the proportion of the $\mathrm{ABO}$ blood groups system in the Osing population were the type of blood O (45.95\%), A (23.99\%), B (21.97\%), and AB (8.09\%). The allele frequencies of $\mathrm{I}^{\mathrm{A}}(0.16), \mathrm{I}^{\mathrm{B}}(0.16), \mathrm{I}^{\mathrm{B}}(0.16)$, and allele frequency of $\mathrm{i}(0.68)$. The Hardy-Weinberg genetic equilibrium test results using the Chi-square test showed no significant deviations.

Keywords: ABO, allele frequency, Osing population, Hardy Weinberg 


\section{PENDAHULUAN}

Desa Kemiren merupakan salah satu desa yang mempunyai beragam budaya tradisi yang unik dan menarik. Desa Kemiren dihuni oleh suku Osing, yang sudah menetap di Banyuwangi sejak masa pemerintahan kerajaan Blambangan tahun 1309 (Maria, 2017, P. 9). Salah satu cara suku Osing Desa Kemiren menjaga adat istiadat peninggalan nenek moyang yaitu dengan melakukan perkawinan upek-upekkan (Rofikoh, 2018). Perkawinan upek-upekkan dapat disebut sebagai perkawinan endogamy yaitu perkawinan yang dilakukan oleh etnis, klan, suku, kekerabatan dalam satu lingkungan yang sama (Rochmawati, 2016). Perkawinan endogami merupakan contoh perkawinan sistem tertutup. Perkawinan tertutup dapat menyebabkan penurunan variasi genetik atau heterozigositas dan peningkatan homozigositas disebabkan anak memperoleh gen yang identik dari kedua orang tuanya. Masing-masing orang tua tersebut memperoleh gen yang identik dari nenek moyang bersama (etim et al, 2011, P. 102). Salah satu sifat genetik yang diwariskan dari orang tua dan tidak dipengaruhi oleh faktor lingkungan adalah golongan darah (Verma \& Agarwal, 1997, P. 326).

Salah satu sistem penggolongan darah yang dikenal adalah sistem ABO. Golongan darah sistem ABO pada manusia dibedakan menjadi 4 macam, yaitu golongan darah $\mathrm{A}, \mathrm{B}, \mathrm{AB}$ dan $\mathrm{O}$, keempat golongan darah tersebut dapat dibedakan menurut antigen yang dimiliki (Elrod \& Stansfield, 2002, P. 125) . Sistem golongan darah $\mathrm{ABO}$ diatur oleh 3 macam alel yaitu $\mathrm{I}^{\mathrm{A}}, \mathrm{I}^{\mathrm{B}}$ dan i. Alel $\mathrm{I}^{\mathrm{A}}$ dan $\mathrm{I}^{\mathrm{B}}$ bersifat dominan terhadap alel i. Namun alel $\mathrm{I}^{\mathrm{A}}$ tidak dominan terhadap alel $\mathrm{I}^{\mathrm{B}}$, demikian juga sebaliknya alel $\mathrm{I}^{\mathrm{B}}$ tidak dominan terhadap ale $\mathrm{I}^{\mathrm{A}}$, sehingga alel $\mathrm{I}^{\mathrm{A}}$ dan $\mathrm{I}^{\mathrm{B}}$ disebut sebagai kodominan (Suryo, 2012, P. 321).

Penyebaran golongan darah $\mathrm{A}, \mathrm{B}, \mathrm{O}$ dan $\mathrm{AB}$ bervariasi di beberapa daerah tergantung populasi atau ras (Garratty, 2004, P. 44). Beberapa penelitian yang telah dilakukan tentang penyebaran golongan darah $\mathrm{ABO}$ pada salah satu populasi penduduk di Indonesia yaitu di kampung Arab Bondowoso menunjukkan proporsi golongan darah A 31,13\%, proporsi golongan darah $\mathrm{B} 25,68 \%$, proporsi golongan darah $\mathrm{AB} 4,28 \%$ dan proporsi golongan darah O 38,91\%. Hasil penelitian menunjukkan persamaan dengan pola penyebaran golongan darah sistem ABO di negara Timur Tengah yang merupakan daerah asal penduduk kampung Arab. Hal ini membuktikan bahwa selama itu penduduk 
kampung Arab melakukan perkawinan dengan sesama suku, sehingga pewarisan gen penentu golongan darah $\mathrm{ABO}$ masih tetap terwarisi dari nenek moyangnya (Ratnawati et al, 2009, P. 246). Puspito (2004), juga melakukan penelitian tentang penyebaran golongan darah ABO pada populasi penduduk Gili Ketapang Kabupaten Probolinggo. Hasil penelitian menunjukkan proporsi golongan darah A 18,8\%, proporsi golongan darah $\mathrm{B} 28,5 \%$, proporsi golongan darah $\mathrm{AB} 3,41 \%$ dan proporsi golongan darah $\mathrm{O}$ $49,29 \%$.

Berdasarkan keadaan suku Osing Desa Kemiren dengan populasi yang cenderung melakukan perkawinan sistem tertutup, maka diduga distribusi dan frekuensi alel golongan darah sistem ABO berbeda dengan populasi yang melakukan perkawinan secara acak. Oleh karena itu, perlu dilakukan penelitian terkait dengan distribusi dan frekuensi alel golongan darah ABO pada populasi suku Osing Desa Kemiren di Kabupaten Banyuwangi.

\section{METODE}

Penelitian dilakukan pada populasi suku Osing Desa Kemiren Kabupaten Banyuwangi. Teknik pengambilan sampel dilakukan menggunakan teknik pengambilan sampel acak. Penduduk yang dijadikan sebagai sampel adalah suku Osing Desa Kemiren dengan usia 15-65 tahun. Jumlah sampel sebanyak 346 jiwa. Data pembanding diambil dari sampel data golongan darah PMI (Palang Merah Indonesia) Kabupaten Banyuwangi sebanyak 400 jiwa.

Jumlah sampel yang diambil dari penduduk Desa Kemiren dan data dari PMI (Palang Merah Indonesia) ditentukan berdasarkan rumus :

$$
n=\frac{N}{1+N\left(d^{2}\right)}
$$

(Notoatmodjo, 2005, P. 124)

Keterangan : $\mathrm{n}=$ Jumlah sampel yang diambil

$\mathrm{N}=$ Jumlah populasi penduduk di lokasi penelitian

$\mathrm{d}=$ penyimpangan terhadap populasi $(0,05)$ 
Berdasarkan rumus diatas diperoleh jumlah sampel (n) suku Osing Desa Kemiren sebanyak:

$$
\mathrm{n}=\frac{2.544}{1+2.544\left(0,05^{2}\right)}=346 \text { jiwa }
$$

Berdasarkan rumus diatas diperoleh jumlah sampel (n) yang diambil dari PMI (Palang Merah Indonesia) sebanyak:

$$
\mathrm{n}=\frac{1.692 .324}{1+1.692 .324\left(0,05^{2}\right)}=400 \text { jiwa }
$$

Identifikasi golongan darah dilakukan dengan metode slide test. Hal pertama yang dilakukan yaitu menyiapkan semua alat dan bahan yang dibutuhkan untuk proses pengujian golongan darah, kemudian tusuk ujung jari dengan blood lancet sampai terlihat adanya tetesan darah, sebelum ujung jari ditusuk harus dibersihkan terlebih dahulu dengan alkohol 70\%. Tetesan darah yang keluar diletakkan ke atas gelas benda sebanyak dua tetes. Selanjutnya tetesi masing-masing tetesan darah dengan serum Anti A dan Anti B. Darah dan serum diaduk menggunakan tusuk gigi hingga homogen. Tetesan yang menggumpal akan mengindikasikan golongan darah dari pemiliknya (Oktari \& Silvia, 2016, P. 2338).

Parameter yang digunakan yaitu, penghitungan proporsi fenotip golongan darah sistem $\mathrm{ABO}$ dan penghitungan frekuensi alel golongan darah sistem $\mathrm{ABO}$. Proporsi fenotip dapat dihitung dengan rumus berikut :

Proporsi jumlah individu dengan fenotipe tertentu dalam populasi Fenotip $=\frac{\text { jumlah sampel dalam suatu populasi }}{\text { Pro }} \times 100 \%$

(Brooker, 2012, P. 150).

Frekuensi alel dihitung berdasarkan hukum kesetimbangan Hardy-Weinberg untuk golongan darah sistem $\mathrm{ABO}$ yang ditentukan oleh 3 alel sebagai berikut :

$$
\begin{gathered}
(\mathbf{p}+\mathbf{q}+\mathbf{r})^{2}=1 \\
\mathbf{p}^{2} I^{\mathrm{A}} \mathbf{I}^{\mathrm{A}}+2 p r I^{\mathrm{A}} \mathbf{i}+\mathbf{q}^{2} \mathbf{I}^{\mathrm{B}} \mathbf{I}^{\mathrm{B}}+2 \mathbf{q} \mathbf{I}^{\mathrm{B}} \mathbf{i}+2 p q I^{\mathrm{A}} \mathbf{I}^{\mathrm{B}}+\mathbf{r}^{2} i \mathrm{i}=\mathbf{1}
\end{gathered}
$$

(Weaver \& Hedrick, 1989, P. 452).

Keterangan: $\quad \mathbf{p}=$ menyatakan frekuensi alel $\mathrm{I}^{\mathrm{A}}$ 


$$
\begin{aligned}
& \mathbf{q}=\text { menyatakan frekunsi alel } \mathrm{I}^{\mathrm{B}} \\
& \mathbf{r}=\text { menyatakan frekunsi alel } \mathrm{i}
\end{aligned}
$$

Analisi data yang digunakan yaitu pengujian kesetimbangan genetik HardyWeinberg terhadap frekuensi alel golongan darah sistem ABO dengan menggunakan uji Chi-square. Analisis data proporsi fenotip dan frekuensi alel dilakukan dengan menggunakan uji Chi-square dengan taraf kepercayaan 95\%, yaitu:

$$
\mathbf{X}^{2}=\sum \frac{(\mathbf{o}-\mathbf{e})^{2}}{\mathbf{e}}
$$

(Tamarin \& Leavitt, 1991, P. 425).

Keterangan : $\mathbf{X}^{\mathbf{2}}=$ nilai uji Chi-square

$\mathbf{e}=$ expected (jumlah fenotip yang diharapkan)

$\mathbf{o}=$ observed (jumlah fenotip yang didapat berdasarkan frekuensi alel yang diketahui)

Tabel 1. Uji Kesetimbangan Genetik Hardy-Weinberg

\begin{tabular}{cccccc}
\hline $\begin{array}{c}\text { Golongan } \\
\text { Darah }\end{array}$ & $\mathrm{O}$ & $\mathrm{E}$ & $(\mathrm{o}-\mathrm{e})$ & $(\mathrm{o}-\mathrm{e})^{2}$ & $(\mathrm{o}-\mathrm{e})^{2} / \mathrm{e}$ \\
\hline
\end{tabular}

A

$\mathrm{B}$

$\mathrm{AB}$

$\mathrm{O}$

Jumlah

$$
\mathrm{X}^{2}=
$$

Keterangan: Jika nilai uji Chi-square $\left(\mathrm{X}^{2}\right)$ lebih besar dari 0,05 maka nilai Chi-square $\left(\mathrm{X}^{2}\right)$ terletak pada tabel disebelah kiri yang menunjukkan bahwa hasil sesuai dengan kesetimbangan HardyWeinberg, namun jika lebih kecil dari 0,05 maka nilai Chi-square $\left(\mathrm{X}^{2}\right)$ ada pada tabel sebelah kanan menunjukkan bahwa penyimpangannya signifikan yang berarti hasil tidak sesuai dengan kesetimbangan Hardy-Weinberg (Tamarin \& Leavitt, 1991, P. 452).

\section{HASIL DAN PEMBAHASAN}

Proporsi fenotip golongan darah sistem ABO pada populasi suku Osing Desa Kemiren dan data dari PMI Kabupaten Banyuwangi dapat dilihat pada Tabel 2.

Tabel 2. Proporsi Fenotip Golongan Darah Sistem ABO pada Populasi Suku Osing Desa Kemiren dan Data PMI 


\begin{tabular}{ccccc}
\hline Golongan Darah & \multicolumn{2}{c}{ Suku Osing Desa Kemiren } & \multicolumn{2}{c}{ Data PMI } \\
\cline { 2 - 5 } & Jumlah & Persentase (\%) & Jumlah & Persentase (\%) \\
\hline A & 83 & $23,99 \%$ & 69 & $17,25 \%$ \\
B & 76 & $21,97 \%$ & 131 & $32,75 \%$ \\
AB & 28 & $8,09 \%$ & 23 & $5,75 \%$ \\
O & 159 & $45,95 \%$ & 177 & $44,25 \%$ \\
Total & 346 & $100 \%$ & 400 & $100 \%$ \\
\hline
\end{tabular}

Menurut Chester \& Olsson (2001, P. 177), golongan darah O paling banyak ditemui karena dapat terbentuk dari banyak kombinasi perkawinan orang tua. Tabel 3. menunjukkan bahwa individu bergolongan darah $\mathrm{O}$ dapat mempunyai parental dengan golongan darah $\mathrm{A}, \mathrm{B}$ dan $\mathrm{O}$. Golongan darah yang memiliki persentase yang terkecil yaitu golongan darah $\mathrm{AB}$ karena hanya dapat terbentuk pada individu dari hasil perkawinan antara golongan darah A dengan golongan darah B.

Tabel 3. Kombinasi Perkawinan Sistem ABO yang Menghasilkan Keturunan Golongan Darah O dan AB

\begin{tabular}{cccc}
\hline $\begin{array}{c}\text { Kombinasi orang } \\
\text { tua }\end{array}$ & Genotip & Fenotip & Persentase fenotip (\%) \\
\hline A X A & I $^{\mathrm{A}^{\mathrm{i}} \text { X I }}{ }^{\mathrm{A}}$ i & O & 25 \\
A X O & $\mathrm{I}^{\mathrm{A}}$ i X ii & O & 50 \\
B X B & $\mathrm{I}^{\mathrm{B}}$ i X I $\mathrm{B}^{\mathrm{B}}$ & $\mathrm{O}$ & 25 \\
B X O & $\mathrm{I}^{\mathrm{A}}$ i X ii & O & 50 \\
O X O & ii X ii & O & 100 \\
A X B & $\mathrm{I}^{\mathrm{A}}$ i X I ${ }^{\mathrm{B}}$ i & O & 25 \\
& $\mathrm{I}^{\mathrm{A}} \mathrm{I}^{\mathrm{A}} \mathrm{X} \mathrm{I}^{\mathrm{B}} \mathrm{I}^{\mathrm{B}}$ & $\mathrm{AB}$ & 25 \\
& $\mathrm{AB}$ & 100 \\
\hline
\end{tabular}

(Tamarin \& Leavitt, 1991, P. 425)

Urutan proporsi fenotip golongan darah system ABO pada populasi suku Osing Desa Kemiren berbeda dengan data dari PMI. Urutan proporsi fenotip golongan darah sistem ABO pada suku Osing juga berbeda dengan beberapa penelitian yang pernah dilakukan di Indonesia diantaranya yaitu, pada populasi pulau Gili Ketapang Kabupaten Probolinggo (Puspito, 2004), pada populasi Kabupaten Lampung Timur (Khoiriyah, 2014, P. 2302), pada populasi Indonesia pada umumnya (Kemenkes, 2018, P. 2442). Hasil penelitian mereka menunjukkan urutan proporsi fenotip berturut-turut yaitu $\mathrm{O}, \mathrm{B}$, 
A, AB. Perbedaan distribusi pola golongan darah pada populasi suku Osing ini diduga dampak perkawinan upek-upekkan yang dilakukan oleh penduduk suku Osing Desa Kemiren, sehingga dapat mempengaruhi struktur genetik yang meliputi proporsi genotip dan fenotip. Hal ini sesuai dengan pendapat Lewin (2002, P. 152), yang menyatakan bahwa perkawinan sistem tertutup akan mempengaruhi struktur genetik. Frekuensi alel golongan darah sistem ABO pada populasi suku Osing dan data PMI Kabupaten Banyuwangi dapat dilihat pada Tabel 4.

Tabel 4. Frekuensi Alel Golongan Darah Sistem ABO Suku Osing Desa Kemiren dan Data PMI

\begin{tabular}{ccc}
\hline Alel & \multicolumn{2}{c}{ Frekuensi Alel } \\
\cline { 2 - 3 } & Suku Osing & Data PMI \\
\hline $\mathrm{I}^{\mathrm{A}}(\mathrm{p})$ & 0,16 & 0,13 \\
$\mathrm{I}^{\mathrm{B}}(\mathrm{q})$ & 0,16 & 0,21 \\
$\mathrm{i}(\mathrm{r})$ & 0,68 & 0,66 \\
\hline Total & 1 & 1 \\
\hline
\end{tabular}

Perbedaan frekuensi alel $\mathrm{I}^{\mathrm{A}}$, $\mathrm{I}^{\mathrm{B}}$, maupun i karena dipengaruhi oleh jumlah sampel. Frekuensi alel i lebih tinggi dari frekuensi alel lainnya pada suku Osing maupun data PMI karena alel i terdapat pada hampir semua golongan golongan darah. Menurut Campbell et al (2010, P. 272) alel i terdapat pada golongan darah A heterozigot, golongan darah B heterozigot dan golongan darah O. Jumlah sampel yang bergolongan darah $\mathrm{O}$ lebih tinggi daripada golongan darah lainnya oleh karena itu golongan darah $\mathrm{O}$ menyumbangkan alel i terbanyak. Frekuensi alel $\mathrm{I}^{\mathrm{A}}$ dan $\mathrm{I}^{\mathrm{B}}$ pada suku Osing memiliki hasil yang sama karena jumlah sampel golongan darah A dan jumlah sampel golongan darah B pada suku Osing memiliki jumlah yang hampir sama. Frekuensi alel $\mathrm{I}^{\mathrm{B}}$ lebih besar daripada frekuensi alel $\mathrm{I}^{\mathrm{A}}$ pada data PMI karena jumlah sampel golongan darah $\mathrm{B}$ lebih besar daripada jumlah sampel golongan darah A. Selain itu frekuensi alel $\mathrm{I}^{\mathrm{A}}$ dan $\mathrm{I}^{\mathrm{B}}$ juga terdapat pada golongan darah $\mathrm{AB}$ yang bernilai sama.

Nilai frekuensi alel suku Osing Desa Kemiren berbeda dengan beberapa penelitian yang pernah dilakukan di Indonesia diantaranya yaitu, pada penduduk Indonesia memiliki frekuensi alel $\mathrm{I}^{\mathrm{A}}$ sebesar 0,17 , frekuensi alel $\mathrm{I}^{\mathrm{B}}$ sebesar 0,20 , dan frekuensi alel i sebesar 0,63 (Kemenkes, 20018, P. 2442). Kabupaten Lampung Timur 
memiliki frekuensi alel $\mathrm{I}^{\mathrm{A}}$ sebesar 0.16, frekuensi alel $\mathrm{I}^{\mathrm{B}}$ sebesar 0,21, dan frekuensi alel i sebesar 0,62 (Khoiriyah, 2014, P. 2302). Pulau Gili Ketapang Kabupaten Probolinggo memiliki frekuensi alel $\mathrm{I}^{\mathrm{A}}$ sebesar 0,12 , frekuensi alel $\mathrm{I}^{\mathrm{B}}$ sebesar 0,17 , dan frekuensi alel i sebesar 0,70 (Puspito, 2004). Populasi kampung Arab Kabupaten Bondowoso memiliki frekuensi alel $\mathrm{I}^{\mathrm{A}}$ sebesar 0,17 , frekuensi alel $\mathrm{I}^{\mathrm{B}}$ sebesar 0,20, dan frekuensi alel i sebesar 0,63 (Ratnawati et al, 2009, P. 246).

Perbedaan nilai frekuensi alel pada suku Osing Desa Kemiren dengan penelitian yang pernah dilakukan di Indonesia diduga disebabkan perkawinan upekepekkan yang dilakukan suku Osing Desa Kemiren. Perkawinan upek-upekkan diduga dapat mempengaruhi jumlah sampel golongan darah dan stuktur genetik yang berkaitan dengan proporsi genotip dan fenotip sehingga mempengaruhi frekuensi alel. Hal tersebut didukung oleh pernyataan Klug \& Cummings (1994, P. 252), bahwa perkawinan tidak acak dapat mengubah proporsi genotip dan fenotip.

Frekuensi alel dalam suatu populasi diuji kesetimbangan genetiknya sesuai dengan hukum genetik Hardy-Weinberg. Pengujian kesetimbangan genetik HardyWeinberg dilakukan menggunakan uji Chi-square, dapat dilihat pada Tabel 5.

Tabel 5. Tabel Uji Kesetimbangan Genetik Hardy-Weinberg pada Populasi Suku Osing dan Data PMI Kabupaten Banyuwangi

\begin{tabular}{lccccccc}
\hline & $\begin{array}{c}\text { Golongan } \\
\text { Darah }\end{array}$ & O & E & $(\mathbf{o - e})$ & $(\mathbf{o - e})^{\mathbf{2}}$ & $(\mathbf{o - e})^{\mathbf{2}} / \mathbf{e}$ & Nilai X $^{\mathbf{2}}$ \\
\hline Suku & $\mathrm{A}$ & 83 & 84,15 & $-1,15$ & 1,32 & 0,02 & 6,78 \\
Osing & $\mathrm{B}$ & 76 & 84,15 & $-8,15$ & 66,38 & 0,79 & \\
& $\mathrm{AB}$ & 28 & 17,72 & 10,28 & 105,78 & 5,97 & \\
& O & 159 & 159,99 & $-0,99$ & 0,98 & 0,00 & \\
\hline Data & $\mathrm{A}$ & 69 & 75,4 & $-6,4$ & 40,96 & 0,54 & 0,69 \\
PMI & $\mathrm{B}$ & 131 & 128,52 & 2,48 & 6,15 & 0,05 & \\
& $\mathrm{AB}$ & 23 & 21,84 & 1,16 & 1,35 & 0,06 & \\
& $\mathrm{O}$ & 177 & 174,24 & 2,76 & 7,62 & 0,04 & \\
\hline
\end{tabular}

Perhitungan Chi-square uji kesetimbangan genetic Hardy-Weinberg pada populasi suku Osing Desa Kemiren dan data PMI dengan taraf signifikasi 95\% $(0,05)$ dapat dilihat pada Tabel 5. Hasil tes Chi-square populasi suku Osing diperoleh nilai 6,78 dengan derajat kebebasan 3, mempunyai nilai probabilitas yang terletak antara 0,20 
dan 0,05. Hasil tes Chi-square data PMI didapatkan nilai 0,69 dengan derajat kebebasan 3, mempunyai nilai probabilitas yang terletak antara 0,95 dan 0,80. Nilai Chi-square yang diperoleh menunjukkan lebih besar dari 0,05.

Berdasarkan nilai Chi-square tersebut menunjukkan bahwa hasil pengujian kesetimbangan genetik Hardy-Weinberg pada populasi suku Osing maupun data PMI menunjukkan tidak ada penyimpangan yang signifikan. Dengan demikian perkawinan upek-upekkan yang dilakukan oleh suku Osing diduga belum mampu mengubah frekuensi alel sehingga dapat dikatakan pada populasi tersebut tidak terjadi perubahan frekuensi alel atau frekuensi alel tetap dari generasi ke generasi. Menurut Amroni (2016, P.1978), jika nilai probabilitas lebih besar dari 0,05 maka nilai probabilitas terletak pada tabel disebelah kiri yang menunjukkan bahwa penyimpangan tidak signifikan yang berarti frekuensi alel tetap dari generasi satu ke generasi berikutnya dan memenuhi hukum kesetimbangan genetik Hardy-Weinberg.

Faktor-faktor yang dapat menyebabkan perubahan frekuensi alel antara lain yaitu: jumlah populasi, mutasi, migrasi, seleksi dan perkawinan tidak acak. Jumlah populasi pada suku Osing cukup besar sehingga beberapa faktor yang dapat menyebabkan perubahan frekuensi alel menjadi tidak berpengaruh signifikan. Hal ini sesuai dengan pernyataan Emery (1992, P. 213) bahwa perubahan frekuensi alel dalam populasi besar tidak terjadi dengan mudah.

\section{KESIMPULAN DAN SARAN}

Proporsi golongan darah sistem ABO pada populasi suku Osing Desa Kemiren secara berurutan yaitu golongan darah $\mathrm{O}, \mathrm{A}, \mathrm{B}$, dan $\mathrm{AB}$. Frekuensi alel masing-masing adalah alel $\mathrm{I}^{\mathrm{A}}(0,16)$, frekuensi alel $\mathrm{I}^{\mathrm{B}}(0,16)$, dan frekuensi alel i $(0,68)$. Hasil tersebut sama dengan beberapa penelitian yang pernah dilakukan di Indonesia. Hasil pengujian kesetimbangan genetik menunjukkan populasi suku Osing Desa Kemiren memenuhi hukum kesetimbangan genetik Hardy-Weinberg.

Perlu dilakukan penelitian lebih lanjut terkait perkawinan inbreeding yang merupakan dampak perkawinan upek-upekkan pada populasi suku Osing-Kemiren, Banyuwangi. 


\section{DAFTAR PUSTAKA}

Amroni. 2016. Penerapan Rule Base Expert System Untuk Mengetahui Hasil Perkawinan Antar Golongan Darah. Jurnal Ilmiah Media SISFO. 10 (2): 19788126.

Brooker, R. J. (2012). Genetics: Analysis \& Principles. McGraw-Hill. New York, United States of America.

Campbell, N. A., J. B. Reece, L. A. Urry, M. L. Cain, S. A. Wasserman, P. V. Minorsky, dan R. B. Jackson. (2010). Biologi. Edisi Kedelapan-Jilid 3. Erlangga. Jakarta.

Chester, M. A. dan M. L. Olsson. (2001). The ABO Blood Group Gene: A Locus of Considerable Genetic Diversity. Transfusion Medicine Reviews. 15(3), 177-200.

Elrod, S. L. dan W. D. Stansfield. (2002). Schaum's Outlines Of Teory And Problems Of Genetics. Fourth Edition. Penerbit Erlangga. Jakarta.

Emery. (1992). Dasar-Dasar Genetika Kedokteran. Yayasan Essentia Medica. Yogyakarta.

Etim, E. A., J. O. Akpotuzor, A. C. Ohwonigho, dan Francis. 2017. Distribution of $\mathrm{ABO}$ and Rhesus Blood Groups Among Selected Tribes in Adamawa State, Nigeria. Hematology \& Transfusion International Journal. 4 (6): 00102.

Garratty, G., S. A. Glynn, dan R. Mcentire. 2004. ABO and Rh(D) Phenotype Frequencies of Different Racial/Ethnic Groups in The United States. Transfusion. Volume 44.

Kementerian kesehatan RI. (2018). Infodatin Pusat Data dan Informasi Kemeterian Kesehatan RI : Pelayanan Darah Di Indonesia. 2442 - 7659.

Khoiriyah, Y. N. (2014). Karakter Genetik Populasi Bedeng 61B Desa Wonokarto Kabupaten Lampung Timur Pasca Program Kolonisasi Pemerintah Belanda. Biogenesis. 2(2), 2302-1616.

Klug, W. S. dan M. R. Cummings. (1994). Concepts of Genetics: Concept of Genetics. Fourth Edition. Macmillan Publishing Company. New York, USA.

Lewin, B. (2002). Genes VII. Oxford University Press. 
Maria, N. (2017). Gerakan Sosial Politik di Blambangan Tahun 1767-1768. Jurnal penelitian sejarah dan budaya. 9 (3).

Notoatmodjo, S. (2005). Metodologi Penelitian Kesehatan. PT Rineka Cipta. Jakarta.

Oktari, A. dan N. D. Silvia. (2016). Pemeriksaan Golongan Darah Sistem ABO Metode Slide dengan Reagen Serum Golongan Darah A, B, O. Jurnal Teknologi Laboratorium. 5(2), $2338-5634$.

Puspito, A. N. (2004). Frekuensi Alel Golongan Darah A, B, O dan Uji Keseimbangan Genetik Hardy-Weinberg pada Populasi Penduduk Pulau Gili Ketapang Kabupaten Probolinggo. Skripsi. Universitas Jember.

Ratnawati, S., R. Oktarianti, dan S. Mumpuni. (2010). Penyebaran dan Frekuensi Alel Golongan Darah ABO pada Populasi Penduduk Kampung Arab di Kabupaten Bondowoso. Jurnal Ilmu Pendidikan MIPA dan MIPA : Saintifika. 10(2), 1411 5433.

Rochmawati, D. A. N. (2016). Hubungan Perkawinan Endogami Dengan Kelainan Bawaan Lahir. AntroUnairdotNet. V(2), 246.

Rofikoh, S. (2018). Strategi Masyarakat Suku Osing Dalam Melestarikan Adat-Istiadat Pernikahan di Tengah Modernisasi (Studi Kasus di Desa Kemiren Kecamatan Glagah Kabupaten Banyuwangi). Skripsi. Universitas Islam Negeri Sunan Ampel Surabaya.

Suryo. (2012). Genetika Untuk Strata 1. Gadjah Mada University Press. Yogyakarta.

Tamarin, R. dan R. W. Leavitt. (1991). Principles Of Genetics. Third Edition. Wm. C. Brown Publishers. United States Of America.

Verma, P.S. dan V.K. Agarwal. (1997). Genetics. S. Chand \& Company Ltd., Ram Nagar. New Delhi.

Weaver, R. F. dan P. W. Hedrick. (1989). Genetics. Wm. C. Brown Publishers. United States of America 